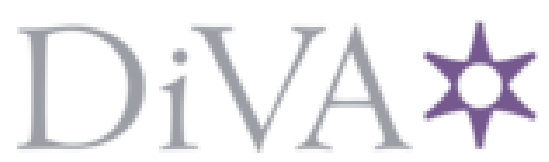

http://www.diva-portal.org

This is the published version of a paper published in Sport Science Review.

Citation for the original published paper (version of record):

Andreasson, J., Johansson, T. (2014)

The Fitness Revolution: Historical Transformations in the Global Gym and Fitness Culture..

Sport Science Review, XXIII(3-4): 91-112

http://dx.doi.org/10.2478/ssr-2014-0006

Access to the published version may require subscription.

N.B. When citing this work, cite the original published paper.

Permanent link to this version:

http://urn.kb.se/resolve?urn=urn:nbn:se:Inu:diva-36682 


\title{
The Fitness Revolution. Historical Transformations in the Global Gym and Fitness Culture
}

\author{
Jesper ANDREASSON ${ }^{1}$ Thomas JOHANSSON ${ }^{2}$
}

\begin{abstract}
$\mathrm{T}$ oday, fitness gyms and private health clubs are a huge global business. Fitness has turned into a folk movement, but not one comparable to the old 20th-century movements, often connected to national sentiments, but instead a highly individualized preoccupation. In this article the historical development of modern gym and fitness culture is described and an analytically developed approach to the understanding of the emergence of this multi-billion-dollar phenomenon is developed. The analysis suggest that the techniques, tools, and physical exercises used today in gyms all over the world are the results of a physical culture developed and refined during the 20th century. The body ideals, exercises, techniques, and the pedagogy of fitness have become an increasingly international enterprise. A tentative analysis of the globalization of gym and fitness culture is developed and presented. Three important and decisive phases in the globalization of gym and fitness culture are identified and analyzed.
\end{abstract}

Keywords: fitness culture, history, body, globalization

\footnotetext{
${ }^{1}$ Department of Sport Science, Linnaeus University, Kalmar, Sweden

2 Department of Education, Communication and Learning, University of Gothenburg, Sweden 
Since the 1970s we have been witnessing a global transformation and massive expansion of the fitness industry. According to the International Health, Racquet \& Sports Club Association (IHRSA), which is the trade association serving the health and fitness club industry, this global "movement" generated an estimated $\$ 75.7$ billion in revenue in 2012, from more than 153,000 health clubs serving 131.7 million members (IHRSA, 2013). In Great Britain, subscriptions to private fitness clubs have risen steadily during recent decades, and a public survey shows that at the beginning of 2000, 14 percent of the population attended a gym (Crossley, 2006). These figures are well in line with studies of the health club population in the United States as well (Sassatelli, 2010), and seem to be increasing continuously across the globe, spurred not the least by strong commercializing forces (Smith Maguire 2008). Consequently, the Bureau of Labour Statistics describes employment in the service-producing industries which focus on the general state of clients' bodies as one of the fastest-growing industries in the sector of US labour market (George, 2008).

The fitness industry and the idea of muscular bodies can be traced to what used to be called physical culture in the late-19th century and to the teachings of the forefathers of bodybuilding such as, for example, Eugene Sandow (18671925) and Charles Atlas (1892-1972) (Budd, 1997; Author, 2013). ${ }^{3}$ Originally, this body subculture was viewed almost exclusively and understood as a male preserve. Another landmark for bodybuilding as a phenomenon can be found in the movie and book Pumping Iron from the late 1970s, where several popular bodybuilders, such as Arnold Schwarzenegger and Lou Ferrigno, are portrayed, while they work out at the famous Gold's Gym in Venice Beach, California (Gaines \& Butler, 1974; Klein, 1993).

The movie Pumping Iron II (1985), portraying four women preparing for the Caesars Palace World Cup Championship, can be seen as a breakthrough for female participation within this subcultural sphere (Author, 2013). This change could be viewed as a starting point for the development of a new, modern fitness culture, where the notion of the gym gradually came to transform and shift from a typically masculine activity into a mass leisure activity. Obviously, gyms reserved solely for hard-core bodybuilding still did and do exist, but they are becoming increasingly marginalized by the large number of premises that find a minimum common denominator in the idea of fitness (Sassatelli, 2010).

\footnotetext{
${ }^{3}$ Although muscle building practices obviously can be found much earlier in history, the emergence of modern fitness culture usually is dated to this time. In the analysis we are mainly analyzing the historical development of modern gym and fitness culture and are therefore not aiming to line up a complete history of muscular bodies. To some extent, we will however, when relevant, point out from 'where' specific cultural expressions may derive even outside this time frame.
} 
The purpose of this article is to describe the historical development of modern gym and fitness culture and to present an analytically developed approach to understanding the emergence of this global multi-billion-dollar phenomenon in contemporary society. The article is to be regarded mainly as a literature review, based on a rich variety of studies describing and analyzing gym and fitness culture, but there is also an ambition to analyze these historical transformations and to develop a theoretical understanding of this phenomenon. Mainly the article will argue that the development of contemporary gym and fitness culture can be analysed and understood through three important and decisive phases of globalization. Different approaches to fitness and to musclebuilding techniques will be explored and situated in a global, historical, and sociocultural framework. In order to understand certain of the trends and tendencies in fitness, the article will focus on a few - but significant - parts of the history of gym and fitness culture. For example, contemporary fitness culture is largely founded within the basic system of ideas developed within bodybuilding. The culture has changed, however, meaning that many of the ideals hailed in this context also have changed. In order to understand some of the developments in contemporary gym and fitness culture, we will argue that it is necessary to re-connect to and analyze some of the early developments in physical culture. Our main focus is centred on the overall transformation from a male-connoted and national muscle culture, to a commercializing industry operating on a global scale, spreading and franchising different conceptions of exercise, diet, lifestyle, and the idea of fitness.

\section{Theoretical framework}

A discussion highly relevant for the article is to be found in the literature on the McDonaldization of society (Ritzer, 2011). Ritzer has developed a concept that can be used to analyze the development of modern and effective organizations, and uses McDonald's, as an example of, and paradigm for, a wide-ranging process in which the principles of the fast-food restaurant increasingly are coming to dominate different sectors of society. Ritzer suggests that there are four alluring dimensions at the heart of the success of the McDonalds model. First, this fast food restaurant offers an efficient method for satisfying many different needs. As such, the model follows a predesigned process which makes it work effectively. Second, people can calculate how much time it will take to get to McDonald's, to order, receive and eat the food. Saving time is crucial here, and McDonald's employees are supposed to do a lot of work, quickly and most often for a low wage. Third, McDonald's offers no surprises. The products and services are highly predictable. Finally, the space created for selling hamburgers, with limited options, allows customers to eat quickly and leave. Thus, this is a highly controlled space, where diners and workers are subsumed under a closely managed system. 
In accordance with the notion of McDonaldization, we will discuss whether and how similar tendencies have permeated the gym and fitness culture. The Americanization thesis has been the topic of considerable debate and discussion. When it comes to the gym and fitness culture, it is highly relevant to discuss how bodybuilding and fitness, and the whole industry connected to them, have been historically imbued with American values and cultural conceptions of beauty, bodies and the individual's responsibility for taking care of and cultivating the body (Melnick \& Jackson, 2002; Monaghan, 2007).

The modern roots of bodybuilding and fitness clearly are to be found in the United States (Klein, 1993). But in relation to this observation, one important question is whether it is possible to talk about a global gym and fitness culture. To what extent are we witness to a relatively homogenized and global form of body and lifestyle ideals? Or should we instead analyze the global spread of gym and fitness in terms of local developments? Urry (2003, see also 2007) describes the relation between the global and local the following way:

'The global and local are inextricably and irreversibly bound together through a dynamic relationship with huge flows of 'resources' moving backwards and forwards between the two. Neither the global nor local exists without the other. The global-local develops in a symbiotic, unstable and irreversible set of relationships in which each gets transformed through billions of worldwide iterations dynamically evolving over time.' (Urry, 2003, p. 84)

This seems to be a nuanced way of approaching and analysing different global phenomena (Ram, 2004; Bale \& Christensen, 2004). There is evidence on the one hand pointing towards local and national approaches to and interpretations of gym and fitness (Steen-Johnson, 2007). But there is also some support on the other hand for the McDonaldization thesis and arguments pointing towards a successively more homogenizing tendency in global gym and fitness culture (Ritzer, 2011). In this article we will analyze the globalization of gym and fitness culture, and identify a number of historically significant transformations in the global gym and fitness industry.

\section{The Pre-history of the gym}

The history of gym culture is a global story of the development of an extensive, international, and commercial business sector. As earlier stated, we are witnessing, during a quite short historical period of time from the 1970s until today, a rather drastic rise in the numbers of commercial fitness gyms, private fitness clubs, franchised chains, international fitness magazines, professional trainers, and so forth (Stern, 2011). 
The modern roots of this culture can be traced back to the early 19th century European Turnhalle (gymnasium) and Friedrich Ludwig Jahn's turnkunst and to the methods for exercise developed by, for example, the Swedish teacher Per Henrik Ling and Niels Bukh in Denmark (Author, 1998). Furthermore, the interest in muscles also was attached to a fascination for the grotesque (Author, 1998). In the late 1800s and early 1900s, for example, there was a growing interest in so-called strongmen who performed in circuses and elsewhere in the United States (Kimmel, 1996). It is possible, of course, to find earlier roots in ancient Greece and Rome. Consequently, there are a number of influences leading successively to contemporary gym and fitness culture. Furthermore, building muscles and devoting time to strengthening the body has been mainly a male preoccupation closely related to warfare, violence, and later on to the building of nation-states - thus, a practice that could be related clearly to what Mosse (1996) refers to as the masculine stereotype.

In the late-19th century the development of physical culture and especially of new techniques used to develop and form a strong, muscular, and masculine body gradually was located in the United States. But this was also an international and especially Western phenomenon, where scientists from different countries turned their attention towards physical culture and physical education. Using influences from the German, Swedish, and Danish gymnastic movement, for example, scientists developed techniques and methods for improving health and strength. The general concern with health and bodies was connected at this time to industrialization and the need for physically capable male bodies. At the beginning of the 1900s, sport and physical culture thereby gradually became a preoccupation for not only the aristocracy, but also workers. This was especially obvious in the totalitarian states of Germany, Italy, and the Soviet Union (Grant, 2013).

One of the central and perhaps most influential profiles in physical culture in the beginning of 20th century was Eugene Sandow. He was born in 1867 in Königsberg, Germany. Sandow started his career as a strongman, working his way through a number of circuses and vaudeville shows. For a long time he toured together with Professor Attila, a physical education teacher. Together they changed the way of looking at weight training and muscles.

'Professor Attila's greatest contribution to Sandow and to weight training in general was his insistence on using heavy weights. This in itself was flying in the face of popular wisdom. It was commonly believed that lifting weights heavier than five or ten pounds would eventually lead the athlete to a condition called muscle binding, in which the unfortunate victim became so muscular that he could not move his limbs.' (Chapman, 1994, p. 10) 
When touring in the United States, Sandow draw great attention to his well-developed body. He gradually became famous; people flocked to watch him flex his muscles and queued up to touch and feel his body. Sandow's fame coincided with the development of modern photography; he was figured on a large number of postcards, and photos of his half-nude body were widespread in different countries.

As late as 1866 it was possible to be prosecuted for indecency for showing a naked leg in Britain, but at the end of the 19th century, pictures of half-nude male bodies were often on display (Budd, 1997). According to Budd (1997), physical culture and profiles such as Sandow's played an important role in this process of change and also in the emergence of homosexual cultures of desire and homosexual communities (cf. Dutton, 2012). Budd writes:

'The question was then not so much one of how same-sex relations between men became criminalized in the period but rather how other male pleasures like those encouraged in physical culture were at the same time asserted as legitimate.' (Budd, 1997, p. 71)

The rapid growth of physical culture and the interest in shaping and sculpting the body must be understood in relation to drastic changes in capitalist societies and the millennium shift. Class roles were changing, and there was a promise of subsuming class differences and transgressing traditional positions. In the midst of this changing social and cultural landscape, urban turmoil, and vibrant commercial culture, the promise of changing one's body and becoming a different and maybe 'better' person attracted both men and women. Physical culture welded together elements of commercial culture and nationalist and imperial ideologies. Social Darwinism and racism melted unproblematic together with promises of individual happiness and possibilities of looking young and fit. At this time physical culture was strongly connected to religion. Training and exercising the body was seen as a way of taking care of God's gift. Within the movement called Muscular Christianity, physical culture was seen as a way to develop a healthy, religious, and morally righteous lifestyle (Green, 1986; Putney, 2001).

Sandow was perhaps one of the first fitness entrepreneurs. He published a magazine and opened an institute for physical culture. He personally met and diagnosed everyone who entered his institute (Chapman, 1994). He diagnosed the problem, gave out a prescription, and wrote down a series of exercises to be performed. He can be seen as an early version of the personal trainer and coach. Sandow was part of a larger development in physical culture. In 1901 he introduced the first bodybuilding contest, in Royal Albert Hall in London, called the Great Competition. Thereafter, the initiative was passed on to people like 
Bernarr Macfadden in the United States and other influential characters such as Charles Atlas (Reich, 2010). They were all part of developing an international and global physical culture. Sandow travelled around the world trying to spread his message and to sell his methods and lifestyle concept. In one sense he was a cultural colonizer, but in another sense he tried to rise above race and ethnicity and saw the universal possibility of improvement of the human body. He saw no hindrances or problems in devotion to physical culture in countries such as India or South Africa. Instead, he saw great possibilities in the similarities of bodies over the whole globe.

Another important icon for the early development of bodybuilding was Charles Atlas (1883-1972). Following the legacy of Sandow, he became famous when he developed and marketed a special exercise programme for bodybuilding. He saw it as his mission to build a perfect race and to contribute to a country of perfect human masterpieces (Kimmel, 1996). Atlas regarded physical culture and muscle building as a part of national salvation. According to Kimmel, the transformations of US society, the world wars, and the changing role of the American father and man led to more or less chronic crises in masculinity (cf. Todd, 1998). American men tried in different ways to defend their gender and to keep up a strong and confident masculinity. Through profiles such as Atlas, the heritage from Muscular Christianity, and the search for a national hero led to the rapid development of physical culture, to the national and international organization of an early fitness industry, and to the development of a modern form of bodybuilding in the 1960s and especially the 1970s. Furthermore, Angelo Siciliano's transformation from an Italian immigrant to the all-American citizen Charles Atlas was also a part of a story of how American men tried to reground and secure manhood. The movement of Muscular Christianity played an important role in this process, not least through the YMCA and the 4,500 gymnasiums connected to this organization in the beginning of the twentieth century (Reich, 2010; Stern, 2011). Reich (2010) argues that the connection between Atlas and mainstream American religious movements distances him from his immigrant roots and de-racializes him. Thus, he is safely positioned in a white, Protestant, American mainstream. These early developments within physical culture and role models such as Sandow and Atlas were forerunners to the bodybuilding culture developed at Gold's Gym and other locations in the 1970s (Hunt, 1989).

Sandow and Atlas laid the ground for a global bodybuilder culture and where probably the first real entrepreneurs in the international fitness business. They traveled, and tried to spread their message on a global scale and can thus be said to represent the first phase towards a globalization of gym and fitness culture. Even though it is possible to identify all the ingredients of a 
globalization of gym and fitness culture - such as magazines, promotional tours, mass production of training tools etc. - this development is still on a very rudimentary level however, and we are quite far from the massive development possible to identify during the 1970 s.

Sandow retired after the war and lived with his wife in a cottage in the countryside outside London. After attempting to lift his car from a muddy ditch, he suffered a stroke and died in 1925. An exemplary plaster cast of Sandow remains in the possession of the Natural History Museum in London. It is kept deep down in the basement, in a bomb shelter (Budd, 1997).

\section{The subculture of bodybuilding}

Today there are a great number of international magazines-such as Ironman, Muscles, Bodypower, Bodybuilding, and Musclemag- devoted entirely to the art of bodybuilding. There are also a manifold of books and manuals available with training programmes. Through different organizations, such as The International Federation of Bodybuilding and Fitness (IFBB), bodybuilding has become a global enterprise and sport. Joseph 'Joe' Weider, who founded the IFBB in 1946, ${ }^{4}$ published one of the first fitness magazines, Your Physique, when he was 18 years old, and at the peak of his career, he owned an empire of fitness magazines and gyms (Luciano, 2001). For example, his Muscle \& Fitness magazine sold more than 400,000 copies in the mid-1970s. At the same time, the famous Gold's Gym had blossomed and developed from a small, shabby, marginal gym into a four-hundred-strong global franchise (Liokaftos, 2012). The film Pumping Iron (1977) put Gold's Gym, Arnold Schwarzenegger, and his friends on the global bodybuilding map.

'Aside from a flashy red, white and blue sign over the door, Gold's Gym is not a very interesting-looking place from the outside. It's a chunky one-story buffcolored building, hunkering close to Pacific Avenue that three steps out the door puts you into the middle of traffic. But inside it's exactly right. In the back there is a small office and a protein bar. Above them are showers and a locker room. All the rest is gym.' (Gaines \& Butler, 1974, p. 34)

When bodybuilding became 'hot' again, everything developed quite rapidly. For quite a long time, bodybuilding was seen as a purposeless and meaningless masculine preoccupation, especially so during the 1960s. The golden period of strongmen in the beginning of the twentieth century was gradually replaced by a long period of a slow development of the fitness business. This does not mean, however, that nothing happened until 1977 and the 'rebirth' of bodybuilding

\footnotetext{
${ }^{4}$ At this time called 'the International Federation of BodyBuilders'.
} 
through Pumping Iron. In Sweden, for example, Arne Tammer became famous when trying to convince the entire Swedish population to spend 15 minutes each day doing strength training and other kinds of exercises (Author, 1998). In the footsteps of Muscular Christianity and similar movements, people like Arne Tammer tried to mobilize the nation. These efforts to engage people in different forms of exercises, especially the ones emphasizing weight training, often regarded modern society as a cause of stress, illnesses, and physical weakness. Through weight training and exercise, modern man could become a part of building a strong nation.

Arnold Schwarzenegger was born in Thal, Austria, in 1947. His father was a police master and his mother a housewife. In the partly autobiographical book Arnold: The Education of a Bodybuilder (Schwarzenegger \& Hall, 1977), his father was described as a rational and self-disciplined man. Schwarzenegger started bodybuilding as a teenager, and at that time, and in Austria, this was not a highly valued physical activity. When Joe Weider called the twenty-one-year-old Arnold in 1968 and asked him to participate in the Mr. Universe competition, he packed his bag and went to the United States. He lost the competition but soon made a comeback and won several competitions in a row. After the success of Pumping Iron, Arnold was drawn into Hollywood and the film industry, and the rest is history.

The interest in bodybuilding, workout techniques, aerobics, and fitness in general exploded in the 1980s. This is a complex history, and there are manifold explanations of why this cultural and body-centered transformation occurred. Susan Jeffords situates this in a historical time of Reagan and Thatcher, war and nationalist movements.

'The Reagan era was an era of bodies. From the anxieties about Reagan's age and the appearance of cancerous spots on his nose; to the profitable craze in aerobics and exercise; to the moulding of a former Mr. Universe into the biggest box-office draw of the decade; to the conservative agenda to outlaw abortion; to the identification of 'value' through an emphasis on drug use, sexuality, and child-bearing; to the thematized aggression against persons with AIDS - these articulations of bodies constituted the imaginary of the Reagan agenda and the site of its materialization.' (Jeffords, 1994, p. 24)

Pumping Iron can be seen as a symbol for the 1980s and as a part of a zeitgeist. However, the reputation and popularity of bodybuilding was negatively affected by the increasing use of performance/image-enhancing drugs during the 1970s and 80s. One reason for the separation between bodybuilding and fitness is also to be found in frequent reports on drug use, anabolic steroids, 
and the obsessional traits of bodybuilders. Through self-confessions, such as Sam Fussell's famous Muscle: Confession of an Unlikely Bodybuilder (1991), the public's images of bodybuilding were coloured and the 'sport' got a bad reputation (Hoberman, 2005).

Sam Fussell, the son of two university professors of English, started bodybuilding at the age of twenty-six. The starting point was a period of ill health and a slowly deteriorating condition. Fussell (1991) was also anxious and had problems adjusting to living in New York. He was filled with fear-then he found bodybuilding. In September 1984 Fussell read Arnold: The Education of a Bodybuilder, and he decided to start pushing weights at a local gym. He described his first experience as follows:

'There was a beautiful simplicity about it. I pushed the iron, and my body grew. The harder I worked, the better I felt. My routine brought order amid chaos. I knew just where to shuffle and when: Deltoids followed pecs, hamstring followed squads. Always twelve reps, always three circuits. I barely paused between exercises, moving from station to station, cable to bar.' (Fussell, 1991, p. 43)

Vividly and in great detail, Fussell brings us into his world. He describes step by step how he became a bodybuilder. He also shows how bodybuilding and the daily exercise turned into a necessity and maybe even a vital condition for survival. He compares his routines and lifestyle to a workaholic devoting himself every hour of the day to work. The gym becomes his second home, and the more he trains, the more he wants to train. He described how his body ached for the pump, that is, the strong sensation achieved when pumping up the muscles to a maximum. Gradually Fussell transforms his body and becomes a bodybuilder. He shaves his whole body, and does anything necessary to step into the role as a full-fledged bodybuilder. But this transformation does not come for free. When arriving in California and at Gold's Gym, he is also entering into the world of steroids.

'From my first moment on the juice, nothing else mattered. Nothing but my workouts, my growth, my meals, my injections, and my friends, who were concerned with their workouts, their growth, their meals, their injections. Everything else was not just secondary - it was positively inconsequential.' (p. 131)

When his personality gradually changes, and he becomes unpleasant and aggressive, he also starts a process of reconsolidation and gradually succeeds in freeing himself from bodybuilding, drugs, and the dependency on four hours of daily exercise. 
Sam Fussell's story is not unique. In the 1990s bodybuilding got a bad reputation and became associated with a fragile, weak masculinity and steroids (Klein, 1993; Denham, 2008; Monaghan, 2001). Academics used bodybuilders as examples of postmodern pastiche and as the example par excellence of a postmodern self (Glasner, 1990; Lindsay, 1996). The status of the huge masculine body has changed over the years (cf. Yang, et al., 2005). In the 1990s and especially in the beginning of 2000s, the negative effects of steroids and drug use were thoroughly investigated, and today there are controls at many gyms. A Danish study shows how fitness franchises, such as SATS and Fitness World, use drug tests to keep up a good reputation, but also to remove bodybuilders from their clientele (Mogensen, 2011).

Today bodybuilding is often described and studied as a subculture (Bridges, 2009). The bodybuilder and the huge muscular male body have an ambivalent position in contemporary culture. Classic film stars and action heroes such as Arnold Schwarzenegger, Sylvester Stallone, and others are still highly valued. At the same time, representations of these kinds of bodies are not unproblematic in everyday life situations, and the bodybuilder is often viewed as something of a freak (cf. McGrath \& Chananie-Hill, 2009). Today it also seems that bodybuilders are quite conscious about the negative effects of this sport. A survey study of the New Zealand bodybuilders conveyed consciousness of the problematic aspects of bodybuilding, such as eating disorders, dependency, and relationship problems (Probert, Leberman \& Palmer, 2007). However, a study of an online bodybuilder community also shows that irrespective of these negative and problematic consequences of bodybuilding, the fans and the dedicated practitioners of this subculture are prepared to take the risks (Smith \& Stewart, 2012).

Bodybuilding and the status of this sport have changed and transformed. From the beginning, it was an almost exclusively male preoccupation. At the beginning of the 20th century and again in the 1970s, bodybuilding attained a high status. In certain countries, and definitely in the United States, bodybuilding certainly was not a subculture, but instead something of a masculine mass movement. Also it seemed that in the beginning of the 20th century and all the way into the 1980s, bodybuilding was mainly a blue-collar and working-class preoccupation (Liokaftos, 2012). Today, bodybuilding has been separated from the concept of fitness and thereby become more or less a subculture populated by men and women and a mix of people, but a larger number of the individuals involved are middle class (Monaghan, 2001).

The development within bodybuilding from the 1970s and onwards - the building of the Weider brother's empire in gym and fitness culture, the stardom of Arnold Schwarzenegger and others, and the mediatization of bodybuilding 
and fitness - can be interpreted as parts of a second phase of the globalization of gym and fitness culture. In contrast to the first phase, the development towards a global culture is accentuated by mediatization of society, and the development of a global business enterprise. The rudimentary development of a global gym and fitness culture during the twentieth century has now been refined, developed and turned into a widespread global business.

During the second phase of the globalization of gym and fitness culture both men and women are involved, and the heavy connotations to working class bodies are replaced by a more diffuse and broad inclusion of both working and middle class participants. This does not mean that all class and gender distinctions are erased from the gym and fitness culture, but merely that from being a more exclusive sport, there is a movement towards a mass participation in fitness.

\section{The fitness revolution}

1968 Kenneth Cooper's groundbreaking book Aerobics was published. This book resulted in a rapid development of different forms of fitness exercises. Later the concept of aerobics also became well-known as a specific form of exercise. The rise of health clubs in the USA was related to a growing urban population of singles, and working out became a part of an urban, middle-class and single lifestyle (Luciano, 2001). Parallel with the development in bodybuilding women like Jane Fonda and others developed a specific form of gymnastics and choreographed movements, labeled as workout.

In the 1980s fitness and workout was still connected to emphasized femininity (Connell, 1995), and to a dutiful housewife. Fonda advocated a life where fitness is compatible with child-care and domestic work. Her videos also targeted an audience of house-wives, making it possible to exercise in front of the television at home (Mansfield, 2011). In the autobiography Fonda (2005) described her lifetime work with fitness and workout. Her first book sold 17 million copies, and she became an important part of the international fitness industry. Fonda released altogether twenty-three workout videos and five workout books during the 1980s and 90s (Mansfield, 2011).

In the 1980s USA workout was first and foremost a preoccupation for the white middle-class. In the late 1980s black women were largely absent from fitness classes (Lau, 2011). This picture changed, however, and in the 1990s workout and fitness became a business for larger parts of the population. The workout techniques and the whole concept of fitness/aerobics were also exported to different countries on a global market. In Sweden, for example, 
Susanne Lanefelt, inspired by Jane Fonda, developed a form of Swedish version of workout. She was successful, and had a television program, and wrote books etc. In one of her books she writes:

'I want to be in control of my body, and I want to feel that my muscles behave the way I want them to. I want to decide where my ass should be, to have welltrimmed legs and a flat stomach.' (Author, 1998, p. 61)

In the 1990s and especially when moving forward to the first two decades of the twenty-first century, there is an explosion of fitness franchises and increasingly more people are drawn into fitness. Whereas workout is the term used in the 1980s, Aerobics is frequently used in the 1990s, but today most people just use the term fitness when talking about fitness gyms, characterized by a mixture of training styles and methods.

In the 1990s in Sweden there was a strong development from the classic weight-training and bodybuilder gyms to multidimensional fitness gyms where different techniques were gathered under one roof. A typical 1990s fitness gym in Sweden consisted of a large room with different types of training machines and gears, a room with classic weights, and one or two rooms for group fitness activities. This development was brought about in different ways and started at different points in various countries. In Sweden the fitness gym in the 1990s was a highly gendered room, where the young men often spent their time in the strength-training parts of the gym and the young women exercised and did workout in other rooms. But a main and crucial development was that the young women gradually found their way into the strength training parts of the gym. In order to develop the 1990s hard body, it became necessary to use barbells and weights or machines. The fitness gym's appearance gradually changed and turned into a more differentiated and individualized space, where gender eventually played a different role.

Aerobics was also exported to Japan. During the 1980s and 1990s, there were great concerns in Japan about the population's general health condition. Statistics showed that Japanese seldom exercised or devoted themselves to physical culture (Spielvogel, 2003). Cooper's book, Aerobics, played a central role in promoting fitness in Japan, and in the beginning of the 1990s there was a rapid growth of fitness centres, particularly in the larger cities. Although this development was influenced by American fitness culture, it was adopted in quite a different way in Japan. The fitness centres took the shape of recreational places, where especially an affluent part of the middle-class population spent their leisure time. At these locations it was possible to exercise, but also to be entertained, eat ice cream, get a massage, and relax. These often exclusive clubs became places where the middle class could relax and develop a consumer 
lifestyle. Rather than spaces of discipline, fitness centres became spaces of luxury (Spielvogel, 2003).

During the 1980s and 90s there is a massive development in gym and fitness culture. This can be described as a third phase of the globalization of this culture. In 1991 there were, for example, 300 fitness gyms in Sweden, and approximately 250,000 individuals exercised in these gyms, whereas the gyms in the beginning of 1980s were few and visited by mostly a small group of enthusiasts and bodybuilder fans. During this period of time, the subculture of bodybuilding was gradually disconnected from a more general trend of fitness gyms and from a conception of the gym as a place for everyone and a mass leisure activity. Sassatelli (2010) captures this development in the following way:

'However since the 1970s there has been a marked increase in the number of exercise premises presenting themselves in a new guise. They have addressed an increasingly large, mixed public. They have shifted the notion of the gym from a sub-cultural passion to a mass leisure activity, intertwined with pop culture.' (Sassatelli, 2010, p. 17)

The cultural and gradual separation between bodybuilding and fitness does not mean that these phenomena become two different activities and lifestyles. These conceptions of exercise and lifestyle partly are disconnected from each other and partly increasingly dependent on each other.

To a certain extent the third phase of the globalization of gym and fitness culture is parallel with the second phase. These developments are organically interwoven and independent. However, the fitness revolution - evolving as a mass enterprise, washing of the stamp of the more grotesque parts of bodybuilding culture, the drugs and the extreme cult of the huge muscular body - also leads to the development of in one sense a more uniform and homogenous global gym and fitness culture, and in another sense to glocal variations in the adaptation of this global 'culture'.

\section{Discussion: Fitness as a global business and lifestyle}

The development of the contemporary fitness culture and industry is the aftermath of complex historical processes. In this article we have pointed towards some of the most central aspects of the transformation of this phenomenon. The main argument put forward in the article is that the transformation and globalization of gym and fitness culture is structured in three different but partly overlapping phases of development. This global enterprise transforms mainly 
through the structural transformations of society and the cultural and social processes of mediatization, and individualization.

It started primarily in the beginning of the twentieth century with entrepreneurs such as Eugene Sandow and Charles Atlas, and later with businessmen such as Bob Hoffman and Joe Weider. Although Bob Hoffman, who built a successful business around barbells and weight training (Fair, 1999), put up a good fight, everything changed when Joe Weider and his brother Ben formed The International Federation of Bodybuilders (IFBB). The membership grew steadily in the 1950s and 1960s, and by the late 1970s there were more than 100 member associations worldwide. In the late 1960s the title Mr. Olympia had been created to bring together the world's top bodybuilders, and bodybuilding thereby became a global business (Dutton, 1995). In 1995 the IFBB boasted 134 affiliated national bodybuilding associations, and it is a member of the General Association of International Sports Federations (GAISF).

In many countries there has been a struggle among certain practitioners to prevent a heavy commercialization of these forms of exercise and the development of whole commercialized lifestyle concepts. In the United States, for example, the YMCA tried for a long time to keep outside the commercial aspects of the business and to make it possible for young people to exercise for free (Miller \& Fielding, 1995). But eventually many organizations have been forced to become regular businesses. Today, fitness gyms and private health clubs are a huge global business. Fitness has become the overall concept used when referring to health clubs, fitness franchises, and fitness gyms. Fitness thereby has turned into a folk movement, but not one comparable to the old 20th-century movements, often connected to national sentiments, but instead a highly individualized and personal task. The blurring of the relation between health and beauty, although manifested in slightly different ways nationally, is a central part of this transformation.

The face of fitness gyms has changed, and it is possible to talk about a fitness revolution. One of the most fascinating parts of this history is the strained but also independent relation developed between bodybuilding and fitness. Whereas bodybuilding often is connoted by things such as drugs, steroids, hyper-masculinity, vanity, hustling, the postmodern self, pastiche, and violence, fitness has come to be connected to health, beauty and youth. This distinction between healthy and unhealthy lifestyles is only a part of the truth about the fitness business. Instead, these two phenomena are interconnected and highly dependent on each other. 
The development of the gym and fitness industry is to a great extent an international and global history. The techniques, tools, and physical exercises used today in gyms all over the world are the results of a physical culture developed and refined during the 20th century. This culture also has roots stretching back to ancient Greece and Rome. In the same way as the development of fashion, for example, was tied to specific times, spaces, and places-Paris, New York, Milan-gym culture travelled in time and space from the Nordic countries and Europe to the United States, and in the 1970s, Gold's Gym and California became the melting pot of bodybuilding and fitness. Another center appeared simultaneously in Montreal, Canada, where Joe and Ben Weider built their global empire of bodybuilding. Through magazines, arrangements of bodybuilding contests, and not least the foundation of the IFBB, the Weider brothers contributed to the globalization of fitness and gym culture.

Although certain places and even specific gyms have played a central role in the history of gym culture, the body ideals, exercises, techniques, and the pedagogy of fitness have become an increasingly international enterprise. Thus, it is not possible to refer to bodybuilding and fitness as a specific American or Canadian phenomenon. But this does not mean that it is impossible to trace tendencies to standardize techniques and exercises used in the global arena of gym culture, which, in a certain sense, can take the form of a McDonaldization of gym culture (Ritzer, 2011). With respect to calculability, for example, fitness activities have resemblances to McDonald's model for success, where it is easy to calculate the time it takes to perform certain activities. Furthermore, the products and services of fitness are more or less identical everywhere, and to some extent predictability rules, when for example looking the franchising systems of group fitness activities developed by Les Mills. During the third phase of the globalization of gym and fitness culture global chains such as Les Mills International points heavily towards a standardization and homogenization of this global culture. The tendency towards homogenization and predictability is also, to some extent apparent when looking at the body ideals that effectively is produced within contemporary gym and fitness culture. It is possible to talk about the construction of a global body ideal, since the 'hard' body, the well-trained, fat-free, clearly-defined, and slimmed body seems to be more or less hegemonic in advertising and consumer culture (Dworkin \& Wachs, 2009).

However, at the same time it is possible to find case studies from different countries throughout the literature, pointing towards both similarities and differences in the way the fitness industry gained its specific national or local form and expression. Spielvogel's (2003) study of fitness in Japan stands out as an example of how the training philosophy and the whole fitness concept are adapted to a specific national culture and specific values. Consequently there are 
important differences between gyms in different places and nations. The aura of exclusivity varies between different gyms. They also promulgate different philosophies, from the working-class gym attending mostly by men, too expensive and luxurious facilities for upper-class men and women (Sassatelli, 2010; Smith Maguire, 2008).

\section{References}

Bale, J. \& Christensen, M. K. (2004). Post-Olympics. Questioning Sport in the Twentyfirst Century. Oxford: Berg.

Bridges, T. S. (2009). Gender Capital and Male Bodybuilders. Body \& Society, 15(1), 83-107.

Budd, M. A. (1997). The Sculpture Machine. Physical Culture and Body Politics in the Age of Empire. London: MacMillan Press.

Bureau of Labor Statistics, U.S. Department of Labor. (2012). Occupational Outlook Handbook, 2012-13 Edition, Projections Overview. Accessed April 18, 2013 at: http://www.bls.gov/ooh/about/projections-overview.htm.

Chapman, D. L. (1994). Sandow the Magnificent. Eugen Sandow and the beginning of Bodybuilding. Chicago: University of Illinois Press.

Connell, R. W. (1995). Masculinities. Cambridge: Polity Press.

Crossley, N. (2006). In the gym: Motives, meaning and moral careers. Body \& Society, 12(3), 23-50.

Denham, B. E. (2008). Masculinities in Hardcore Bodybuilding. Men and Masculinities, 11(2), 234-42.

Dutton, K. R. (1995). The Perfectible Body. The western Ideal of Physical development. London: Cassell.

Dutton, K.R. (2012). The Self Contained Body. The Heroic and Aesthetic/ Erotic Modes of Representing the Muscular Body. In Locks, A \& Richardson, N (ed.). Critical Readings in Bodybuilding. New York/London: Routledge. 
Dworkin, S.L. \& Wachs, L. (2009). Body Panic.Gender, health, and the Selling of Fitness. New York: New York University Press.

Fair, J. D. (1999). Muscletown USA. Bob Hoffman and the Manly Culture of York Barbell. Pennsylvania University Park: The Pennsylvania State University Press.

Fonda, J. (2005). My Life So Far. New York: Random House.

Fussell, S. (1991). Muscles. The Confession of an Unlikely Bodybuilder. New York: Scribner's.

Gaines, C., \& Butler, G. (1974). Pumping Iron.The Art and Sport of Bodybuilding. London: Sphere Books Ltd.

George, M. (2008). Interactions in Expert Service Work. Demonstrating Professionalism in Personal Training. Journal of Contemporary Ethnography, 37, 108-31.

Glasner, B. (1990). Fit for Postmodern Selfhood. In Becker, H. S., and McCall, M. M. (editors) Symbolic Interaction and Cultural Studies, pp. 215-243. Chicago: The University of Chicago Press.

Grant, S. (2013). Physical Culture and Sport in Soviet Society. Propaganda, Acculturation, and Transformation in the 1920s and 1930s. London: Routledge.

Green, H. (1986). Fit for America. Health, Fitness, Sport and the American Society. Baltimore: The Johns Hopkins University Press.

Hoberman, J. (2005). Testosterone Dreams.Rejuvenation, Aphrodisiac, Doping. Berkeley: University of California Press.

Hunt, W.R. (1989). Body Love. The amazing career of Bernarr Macfadden. Bowling Green: Bowling Green State University Press.

IHRSA. (2013). The 2013 IHRS A Global Report. The state of the Health Club Industry. Boston: IHRSA.

Jeffords, S. (1994). Hard Bodies. Hollywood Masculinity in the Reagan Era. New Brunswick: Rutgers University Press.

Kimmel, M. (1996). Manhood in America. A Cultural History. New York: The Free Press. 
Klein, A. M. (1993). Little big men. Bodybuilding subculture and gender construction. New York: State University of New York Press.

Lau, K. J. (2011). Body Language. Sisters in Shape, Black Women's Fitness, and Feminist Identity Politics. Philadelphia: Temple University Press.

Lindsay, C. (1996). Bodybuilding: A Postmodern Freak Show. In Thomson, R.G. (ed.). Freakery. Cultural Spectacles of the Extraordinary Body. New York: New York University Press.

Liokaftos, D. (2012). From 'Classical' to Freaky'. An exploration of the development of dominant, organised male bodybuilding culture. London: Goldsmith's College, PhD.

Luciano, L. (2001). Looking Good: Male Body Image in Modern America. New York: Hill and Wang.

McGrath, S., \& Chananie-Hill, R. (2009). 'Big Freaky-Looking Women'. Normalizing Gender Transgression through Bodybuilding. Sociology of Sport Journal, 26, 235-254.

Mansfield, L. (2011). 'Sexercise': Working out Heterosexuality in Jane Fonda's Fitness Books, Leisure Studies, 30(2), 237-55.

Melnick, J. M. \& Jackson, S. J. (2002) ‘Globalization American-Style and Reference Selection: The Importance of Athlete Celebrity Others among New Zealand Youth'. International Review for the Sociology of Sport, 37(3-4), 429-448.

Miller, L. K., \& Fielding, L. W. (1995). The battle between the For-Profit Health Club and the "Commercial" YMCA. Journal of Sport and Social Issues, 19, February.

Mogensen, K. (2011). Body Punk. En afhandling om mandlige kropsbyggere og kroppens betydninger $i$ lyset av antidoping kampagner [Body Punk. A Thesis on male bodybuilders and the meanings of the body in the light of anti-doping campaigns]. Roskilde: Roskilde Universitetscenter.

Monaghan, L. (2001). Bodybuilders drugs and risk. Health, risk and society. New York: Routledge.

Monaghan, L. F. (2007). McDonaldizing men's bodies? Associated (ir)rationalities and resistances. Body \& Society, 13(2), 67-93. 
Mosse, G. (1996). The image of man. The Creation of Modern Masculinity. New York/ Oxford: Oxford University Press.

Probert, A., Leberman, S., \& Palmer, F. (2007). New Zealand Bodybuilder Identities. International Review for the Sociology of Sport, 42(1), 5-26.

Putney, C. (2001). Muscular Christianity. Manhood and Sports in Protestant America, 1880-1920. Cambridge, Massachusetts: Harvard University Press.

Ram, U. (2004). Glocommodification: How the Global Consumes the Local McDonald's in Israel. Current Sociology, 52(1), 11-31.

Reich, J. (2010). The World's most Perfectly Developed Man. Charles Atlas, Physical Culture, and the Inscription of American Masculinity. Men and Masculinities, 12(4), 444-461.

Ritzer, G. (2011). The McDonaldization of Society 6. London: SAGE.

Sassatelli, R. (2010). Fitness Culture.Gyms and the Commercialisation of Discipline and Fun. New York: Palgrave Macmillan.

Schwarzenegger, A., \& Hall, D. K. (1977). Arnold: The Education of a Bodybuilder. New York: Simon \& Schuster.

Smith, A. C. T., \& Stewart, B. (2012). Body Perception and health Behaviours in an Online Bodybuilding Community. Qualitative Health Research, 22(7), 971-85.

Smith Maguire, J. (2008). Fit for Consumption. Sociology and the business of fitness. London/New York: Routledge.

Spielvogel, L. (2003). Working out in Japan. Shaping the female body in Tokyo fitness clubs. Durham, NC: Duke University Press.

Steen-Johnsen, K. (2007). Globalized Fitness in the Norwegian Context. International Review for the Sociology of Sport, 42(3), 343-62.

Stern, M. (2011). Real or Rogue Charity? Private Health Clubs vs. the YMCA, 19702010. Business and Economic History, On-Line, 9.

Todd, J. (1998). Physical Culture and the Body Beautiful. Purposive Exercise in the Lives of American Women 1800-1870. Macon, Georgia: Mercer University Press. 
Urry, J. (2003). Global Complexity. Cambridge: Polity Press.

Urry, J. (2007) Mobilities. Cambridge: Polity Press.

Yang, C. F. J., Gray, P., \& Pope, H. (2005). Male body image in Taiwan versus the West: Yanggang Zhiqi meets the Adonis complex. American Journal of Psychiatry, 162(2), 263-269.

Jesper ANDREASSON is currently a docent in sport science at Linnaeus University, Sweden. He earned his PhD in sociology at Lund University in 2007. He has written mainly in the field of gender studies, the sociology of sport and gym/fitness culture. Andreasson has published articles in journals such as Journal of Ethnography and Education, Journal of Men's studies, Journal of Sport, Education and Society, and SAGE Open. Among his books are: "The Global Gym. Gender Health, and Pedagogies" (2014, with Thomas Johansson).

\section{Corresponding address:}

Jesper Andreasson,

Linnaeus University, Department of Sport Science,

39182 Kalmar,

Sweden

E-mail: Jesper.andreasson@lnu.se

Phone: +46 480446091

Thomas JOHANSSON is professor of education at the department of Education, Communication and Learning, University of Gothenburg, Sweden. He has written extensively on youth culture, the sociology of the family and masculinity. Among his books are: Social psychology \& Modernity (2000), The Transformation of Sexuality (2007), and Young Migrants (2012, with Katrine Fangen and Nils Hammarén). He can be contacted at: thomas.johansson@ped.gu.se 
